\title{
Properties of Barium-Strontium Titanate Dielectrics
}

\author{
By Elmer N. Bunting, George R. Shelton, and Ansel S. Creamer
}

\begin{abstract}
The results on barium-strontium titanates are given for heat treatments, absorption, shrinkage, thermal expansion, dielectric constant $(K)$ at $-60^{\circ}$ to $85^{\circ} \mathrm{C}$, and also for $Q$, the reciprocal of the power factor, at $25^{\circ} \mathrm{C}$ for frequencies of 50 to $20,000 \mathrm{kc} / \mathrm{s}$. A few measurements of $K$ and $Q$ were made at $3,000 \mathrm{mc} / \mathrm{s}$. Specimens matured (absorption less than 0.1 percent) at $1,250^{\circ}$ to $1,430^{\circ} \mathrm{C}$. $K$ values ranged from 34 , for $\mathrm{BaO}: 4 \mathrm{TiO}_{2}$, to several thousand for specimens with compositions on the $\mathrm{BaTiO}_{3}-\mathrm{SrTiO}_{3}$ join. Specimens having the composition $\mathrm{BaO}: 5 \mathrm{TiO}_{2}$ were unique in that their temperature coefficient of $K$ was practically zero. $Q$ values ranged from 50 to 100 for test pieces containing over 40 percent of $\mathrm{BaO}$, and from 400 to 10,000 for those with less than 40 percent of $\mathrm{BaO}$. $K$ values did not change appreciably with frequency. Linear thermal expansions between $25^{\circ}$ and $700^{\circ} \mathrm{C}$ ranged from 0.6 to 0.84 percent. Many of these specimens could be used in radio equipment.
\end{abstract}

\section{Introduction}

The properties of titanates containing barium and strontium have been investigated only recently $[1,2,3],{ }^{1}$ although dielectrics containing titanium have been used in radio equipment since 1925 [4], and the high values of the dielectric constant of some of the oxides of titanium have been known since 1903 [5]. Many patents have been issued covering the preparation of dielectrics from titania in combination with such oxides as $\mathrm{MgO}, \mathrm{ThO}_{2}, \mathrm{ZrO}_{2}, \mathrm{SiO}_{2}$ and as titania-filled organic plastics. Some of the titanates were conspicuous because they exhibited outstandingly high values of the dielectric constant [1]. Although many data have been published [1, 2, 3] on specific titanates, a knowledge is desirable of the properties of such materials over a wide range of compositions. In 1944 a systematic study of ceramic dielectrics, of which this paper constitutes the first report, was undertaken at the request of the Army Signal Corps.

\section{Preparation of Specimens}

A stock of titania, designated TMO, together with chemically pure quality barium and strontium

\footnotetext{
1 Figures in brackets indicate the literature references at the end of this paper.
}

carbonates, were used in the preparation of all specimens with compositions shown in figure 1. Three other grades of titania were tested also.

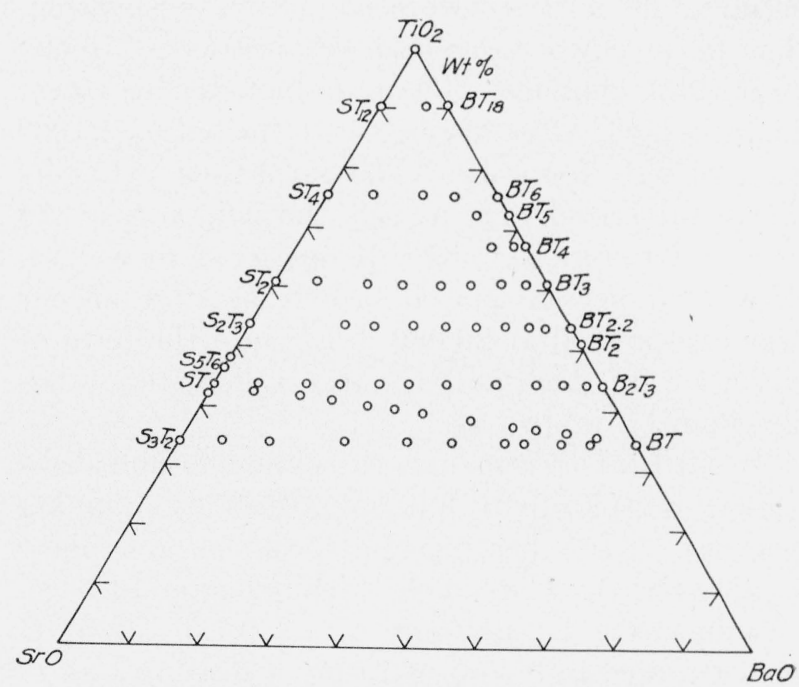

Figure 1.-Ternary diagram for the system $\mathrm{BaO}-\mathrm{SrO}-\mathrm{TiO}_{2}$, showing compositions studied.

$\mathrm{B} \times \mathrm{BaO} ; \mathrm{S}=\mathrm{SrO} ; \mathrm{T}=\mathrm{TiO}_{2}$.

The chemical analysis, furnished by the maker, and some properties of each of the four grades are given in table 1 . 
TABLE 1.-Composition, specific surface, and crystal form of four brands of commercial titanium dioxide, and also the heattreatments and properiies of specimens prepared from these materials

\begin{tabular}{|c|c|c|c|c|c|c|c|c|c|c|c|}
\hline \multirow{2}{*}{ Grade designation } & \multicolumn{3}{|c|}{ Composition a } & \multirow{2}{*}{$\begin{array}{l}\text { Specific } \\
\text { surface b }\end{array}$} & \multirow{2}{*}{ Crystal form c } & \multirow{2}{*}{\multicolumn{2}{|c|}{$\begin{array}{l}\text { Heat treatments for } 1 \mathrm{hr} \\
\text { at- }\end{array}$}} & \multirow{2}{*}{$\begin{array}{l}\text { Shrink- } \\
\text { age d }^{\text {d }}\end{array}$} & \multirow{2}{*}{$\begin{array}{l}\text { A bsorp- } \\
\text { tiond }\end{array}$} & \multirow{2}{*}{$\begin{array}{c}\text { Dielectric } \\
\text { constant } \\
(K) \text { at } 25^{\circ} \mathrm{C} \\
\text { and } 1,000 \\
\mathrm{ke} / \mathrm{s}\end{array}$} & \multirow{2}{*}{$\begin{array}{c}\text { Reciprocal } \\
(Q) \text { of } \\
\text { power fac- } \\
\text { tor at } 25^{\circ} \mathrm{C} \\
\text { and } 1.000 \\
\mathrm{kc} / \mathrm{s}\end{array}$} \\
\hline & $\mathrm{TiO}_{2}$ & $\mathrm{SiO}_{2}$ & $\mathrm{Al}_{2} \mathrm{O}_{3}$ & & & & & & & & \\
\hline \multirow{4}{*}{$T M O$} & $W t \%$ & $W t \%$ & $W_{t} \%$ & $c m^{2} / g$ & & $\begin{array}{l}{ }^{\circ} \mathrm{C} \\
1,100\end{array}$ & $\begin{array}{l}{ }^{\circ} \mathrm{C} \\
1,305\end{array}$ & $\begin{array}{r}\text { Percent } \\
14.1\end{array}$ & $\begin{array}{r}\text { Percent } \\
3.33\end{array}$ & 76 & 182 \\
\hline & 98.7 & 0.25 & 0.2 & 39,000 & Rutile & 1,100 & 1,350 & 16. 6 & 0.72 & 87 & 1,000 \\
\hline & & & & & & 1,100 & 1,400 & 17. 6 & .02 & 91 & 5,200 \\
\hline & & & & & & 1,100 & 1,305 & 7.5 & 10.50 & 42 & 7 \\
\hline \multirow[t]{3}{*}{$W D \ldots \ldots \ldots$} & 98.7 & .4 & .03 & 36,000 & .....do_ & 1,100 & 1,350 & 9.5 & 9. 62 & 49 & 6 \\
\hline & & & & & & 1,100 & 1,425 & & 7.02 & (e) & (e) \\
\hline & & & & & & 1,100 & 1,305 & 18.3 & 0.00 & 97 & 7,000 \\
\hline \multirow{3}{*}{$R$} & 98.2 & .5 & .1 & 27,000 & .....do do... & 1,100 & 1,350 & 19. 6 & .01 & 98 & 7,700 \\
\hline & & & & & & 1,100 & 1,400 & 18.9 & .01 & 98 & 8,800 \\
\hline & 98.8 & .2 & f. 2 & 8,000 & Anatase & 1,400 & None & 15.8 & .00 & 97 & 4,700 \\
\hline
\end{tabular}

a Compositions furnished by maker.

b Determined by R. L. Blaine with the Lea-Nurse apparatus, air-permeability method.

- Determined by X-ray diffraction by H. F. McMurdie.

d Values obtained after final heat treatment.

e Conductance too high for measurement.

A Also contains $0.45 \%$ alkali.

Weighed batch constituents were added to distilled water containing a wetting agent (2 drops of aerosol per $250 \mathrm{ml}$ of water), and the suspension stirred for $1 \mathrm{hr}$ with a high-speed stirrer. After drying the caked mixture it was passed through a No. 50 sieve and moistened with 10 percent, by weight, of a 2 1/2-percent starch suspension. The moist powder was then dry-pressed at 10,000 $\mathrm{lb} /$ in. $^{2}$ into cylinders $(5 / 8 \mathrm{in}$. in diameter by $3 / 4 \mathrm{in}$. long), which, after drying, were heated at $1,100^{\circ}$ to $1,245^{\circ} \mathrm{C}$ for $1 \mathrm{hr}$. These calcined cylinders were pulverized and passed through a No. 325 sieve. After moistening with 5 percent, by weight, of a $21 / 2$-percent starch suspension, the powder was dry-pressed at $20,000 \mathrm{lb} /$ in. $^{2}$ into the form of disks $1 / 8 \mathrm{in}$. thick and of various diameters ranging from $1 / 4$ in. to $1 \mathrm{in}$.

In all heat treatments, the cylinders and disks rested on platinum foil supported by alumina plaques. After heating the specimens overnight to about $1,000^{\circ} \mathrm{C}$ in an electrically heated furnace, the maturing temperature of $1,250^{\circ}$ to $1,430^{\circ} \mathrm{C}$ was attained in 3 to $5 \mathrm{hr}$, using a heating rate of about $3 \operatorname{deg} \mathrm{C}$ a min, and was held for either 1 or $2 \mathrm{hr}$ within $\pm 5 \mathrm{deg} \mathrm{C}$ of the desired temperature. The furnace heating chamber was heated on all sides and was uniform in temperature within $\pm 5 \mathrm{deg}$ C. All temperatures were measured with calibrated $\mathrm{Pt}$ to $\mathrm{Pt}-\mathrm{Rh}$ thermocouples.

\section{Test Methods}

Absorption was determined by immersing the weighed specimen in chemically pure carbon tetrachloride, where it remained while the liquid was boiled for $5 \mathrm{hr}$ and allowed to cool. After quickly drying the surface of the specimen, it was weighed in a stoppered bottle. Carbon tetrachloride was used instead of water to avoid any hydration of the specimens. Any gain in weight was divided by the density of the $\mathrm{CCl}_{4}$ in order to find the equivalent gain, had water been used. Percentage absorption equals equivalent gain in weight, divided by dry weight, multiplied by 100 . The percentage of shrinkage was obtained from the diameter of the mold used, minus the average diameter of the matured specimen, divided by the diameter of the mold, multiplied by 100 .

The dielectric constant $(K)$, and the $Q$-value, ${ }^{2}$ were obtained from measurements on a Boonton "Q" meter, type 160-A, whose condenser had been calibrated against a calibrated precision condenser. This meter was operated in a cabinet controlled at $25^{\circ} \pm 0.5^{\circ} \mathrm{C}$ and a relative humidity of 40 percent or less. The titanate specimens were heavily coated on both sides with a silver

\footnotetext{
2 This value constitutes a "figure of merit" in radio-circuit design, and when greater than 10 , is nearly equal to the reciprocal of the cosine of the phase angle $(\theta)$. High $Q$-values for inductors and condensers are necessary
} for good selectivity in tuned circuits. 
paste and heated to $750^{\circ} \mathrm{C}$ in an electric muffle furnace to give silver electrodes about $0.01 \mathrm{in}$. thick. Any extraneous silver on the side of a disk was removed with fine sandpaper. Specimens were kept at a relative humidity of 40 percent or less and at room temperature for several hours and then at $25^{\circ} \pm 0.5^{\circ} \mathrm{C}$ for $1 / 2 \mathrm{hr}$ before the measurements were made. Disks with a capacity greater than the capacity used in the variable condenser in the instrument were measured in series with a suitable condenser.

The capacitance from which the dielectric constant was computed was determined at $1,000 \mathrm{kc} / \mathrm{s}$, and temperatures ranging from $-60^{\circ}$ to $+85^{\circ} \mathrm{C}$, by the resonant circuit $^{3}$ capacity substitution method. The specimens were held between brass electrodes in an insulated chamber $1 \mathrm{ft}^{3}$ in volume. This chamber could be cooled with dry ice or heated by a heating coil, and was controlled to $\pm 0.25^{\circ} \mathrm{C}$. Measurements were made at $+40^{\circ}$, $+60^{\circ},+80^{\circ},+85^{\circ},+70^{\circ},+50^{\circ},+30^{\circ},+20^{\circ}$, $0^{\circ},-20^{\circ},-40^{\circ},-60^{\circ},-50^{\circ},-30^{\circ},-10^{\circ}$, and $+10^{\circ}$ C. Prior to each measurement, the temperature of the specimen was maintained constant for 15 or more minutes.

Measurements at a frequency of $3,000 \mathrm{mc} / \mathrm{s}$ were made on specially shaped specimens in the Massachusetts Institute of Technology coaxial wave guide instrument [6].

Thermal-expansion determinations were made by the interferometer method at a heating rate of $2 \frac{1}{2}$ to 3 deg $\mathrm{C}$ a minute.

\section{Results and Discussion}

One of the difficulties encountered in the preparation of titanate dielectrics is the lack of uniformity in commercial grades of titanium dioxide. The four grades investigated varied not only in composition but also in grain size and

${ }^{3} \mathrm{~A}$ Hartley oscillator containing a No. 71A tube was used. This was powered on the filament and plate by storage batteries. Resonance was determined on a loosely coupled pick-up circuit, tuned by a precision condenser, and current was indicated by a vacuum thermocouple, using a galvanometer, lamp, and scale. crystal structure. Consequently, matured specimens of impure $\mathrm{TiO}_{2}$ did not exhibit identical properties, as illustrated by the data in table 1 . Such results, showing grade $W D$ to be the least satisfactory for preparing dielectrics of this type, may not warrant the rejection of a given grade for the preparation of dielectrics that contain other materials, such as $\mathrm{BaO}$ or $\mathrm{SrO}$. In the experiments on three grades (table 2), the choice of grade was immaterial so far as the properties of matured specimens of $\mathrm{SrTiO}_{3}$ was concerned. The maturing temperature and other properties of specimens may vary considerably for some specimens when different grades of $\mathrm{TiO}_{2}$ are used.

In table 3 data are given on the composition, heat treatment; absorption; shrinkage; dielectric constant $(K)$; and $Q$, the reciprocal of the power factor, for matured specimens of the titanates studied.

TABLE 2.-Properties of barium and strontium titanate specimens prepared from three grades of commercial titanium dioxide

\begin{tabular}{c|c|c|c|c|c}
\hline & $\begin{array}{c}\text { Heat treat- } \\
\text { ments }\end{array}$ & Shrink- \\
$\begin{array}{c}\text { Grade of } \\
\mathrm{TiO}_{2}\end{array}$ & $\begin{array}{c}\text { Temper- } \\
\text { ature }\end{array}$ & Time & $\begin{array}{c}\text { Absorp- } \\
\text { tion }\end{array}$ & $\begin{array}{c}\text { Dielectric } \\
\text { constant } \\
(K) \text { at } 25^{\circ} \mathrm{C} \\
\text { and } 1,000 \\
\mathrm{kc} / \mathrm{s}\end{array}$ & $\begin{array}{c}\text { Reciprocal } \\
(Q) \text { of } \\
\text { power } \\
\text { factor at } \\
25^{\circ} \mathrm{C} \text { and } \\
1,000 \mathrm{ke} / \mathrm{s}\end{array}$ \\
\hline
\end{tabular}

Specimens of $\mathrm{BaO}: \mathrm{TiO}_{2}$

\begin{tabular}{l|r|r|r|r|r|r}
\hline & ${ }^{\circ} C$ & \multicolumn{1}{c|}{$h r$} & Percent & Percent & & \\
TMO & 1,385 & 2 & 10.6 & 0.05 & 1,500 & 100 \\
$W D \ldots \ldots$ & 1,400 & 1 & 10.9 & .03 & 1,650 & 74 \\
$R \ldots \ldots$ & 1,400 & 1 & 6.9 & 1.07 & 1,300 & 144 \\
\hline
\end{tabular}

Specimens of $\mathrm{SrO}: \mathrm{TiO}_{2}$

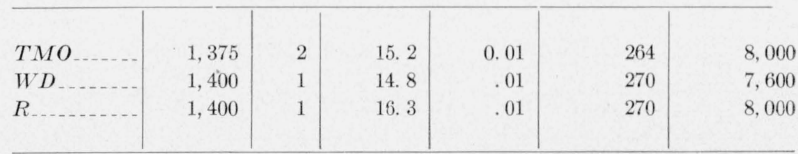

Specimens of $57.4 \%$ SrO: $\mathrm{TiO}_{2}+42.6 \%$ of $\mathrm{BaO}: \mathrm{TiO}_{2}$

\begin{tabular}{|c|c|c|c|c|c|c|}
\hline TMO & 1,420 & 2 & 13. 7 & 0.00 & 680 & 10,000 \\
\hline$W D$ & 1,430 & 1 & 10. 7 & 2. 44 & 655 & 31 \\
\hline$R \ldots$ & 1,430 & 1 & 9.7 & 2. 22 & 605 & 4,800 \\
\hline
\end{tabular}

all preparations were given a preliminary calcination at $1,245^{\circ} \mathrm{C}$ for $1 \mathrm{hr}$. 
TABLE 3.-Composition, heat treatment, absorption, shrinkage, dielectric constant, $K$, and $Q$, of bodies in the system $\mathrm{BaO}-\mathrm{SrO}-\mathrm{TiO}_{2}$

\begin{tabular}{|c|c|c|c|c|c|c|c|c|c|c|c|c|c|c|c|}
\hline \multirow{2}{*}{$\begin{array}{l}\text { Specimen } \\
\text { designation }\end{array}$} & \multirow{2}{*}{$\begin{array}{l}\text { Proportion of } \\
\text { end members } \\
\text { of join }\end{array}$} & \multicolumn{3}{|c|}{ Composition weight } & \multicolumn{3}{|c|}{ Heat treatment } & \multirow{2}{*}{$\begin{array}{l}\text { Ab- } \\
\text { sorp- } \\
\text { tion }\end{array}$} & \multirow{2}{*}{$\begin{array}{c}\text { Shrink- } \\
\text { age }\end{array}$} & \multicolumn{3}{|c|}{$\begin{array}{c}\text { Dielectric constant, } \\
K \text {, at } 25^{\circ} \mathrm{C} \text { and- }\end{array}$} & \multicolumn{3}{|c|}{$\begin{array}{l}\text { Reciprocal, } Q \text {, of power } \\
\text { factor at } 25^{\circ} \mathrm{C} \text { and- }\end{array}$} \\
\hline & & $\mathrm{BaO}$ & $\mathrm{SrO}$ & $\mathrm{TiO}_{2}$ & $\begin{array}{l}1 \mathrm{hr} \\
\text { at- }\end{array}$ & $\begin{array}{l}\text { Tem- } \\
\text { pera- } \\
\text { ture }\end{array}$ & Time & & & $\begin{array}{c}50 \\
\mathrm{kc} / \mathrm{s}\end{array}$ & $\begin{array}{l}1,000 \\
\mathrm{kc} / \mathrm{s}\end{array}$ & $\begin{array}{c}20,000 \\
\mathrm{ke} / \mathrm{s}\end{array}$ & $\begin{array}{c}50 \\
\mathrm{kc} / \mathrm{s}\end{array}$ & $\begin{array}{l}1,000 \\
\mathrm{kc} / \mathrm{s}\end{array}$ & $\begin{array}{c}20,000 \\
\mathrm{ke} / \mathrm{s}\end{array}$ \\
\hline
\end{tabular}

$\mathrm{SrO}: 12 \mathrm{TiO}_{2} \quad \mathrm{BaO}: 18 \mathrm{TiO}_{2}$

\begin{tabular}{|c|c|c|c|c|c|c|c|c|c|c|c|c|c|c|c|c|}
\hline ST12_. & $\begin{array}{c}\text { Weight } \\
\text { percent } \\
100\end{array}$ & $\begin{array}{r}\text { Weight } \\
\text { percent } \\
0\end{array}$ & Percent & $\begin{array}{c}\text { Percent } \\
9.8\end{array}$ & $\begin{array}{c}\text { Percent } \\
90.2\end{array}$ & $\begin{array}{l}{ }^{\circ} \mathrm{C} \\
1,100\end{array}$ & $\begin{array}{l}{ }^{\circ} C \\
1,310\end{array}$ & $\begin{array}{l}h r \\
\quad 1\end{array}$ & $\begin{array}{c}\text { Percent } \\
0.00\end{array}$ & $\begin{array}{c}\text { Percent } \\
16.2\end{array}$ & 113 & 113 & 114 & 2,500 & 3,500 & 2,000 \\
\hline $18 \mathrm{BS} 6 \ldots$ & 36 & 64 & 6.2 & 3.5 & 90.3 & 1,100 & 1,275 & 1 & .00 & 16.6 & 83 & 82 & 82 & 1,200 & 5,400 & 6,700 \\
\hline BT18 & 0 & 100 & 9.6 & 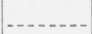 & 90.4 & 1,100 & 1,275 & 1 & .00 & 15.0 & 75 & 74 & 74 & 260 & 1,000 & 7,000 \\
\hline
\end{tabular}

SrO: $4 \mathrm{TiO}_{2} \quad \mathrm{BaO}: 6 \mathrm{TiO}_{2}$

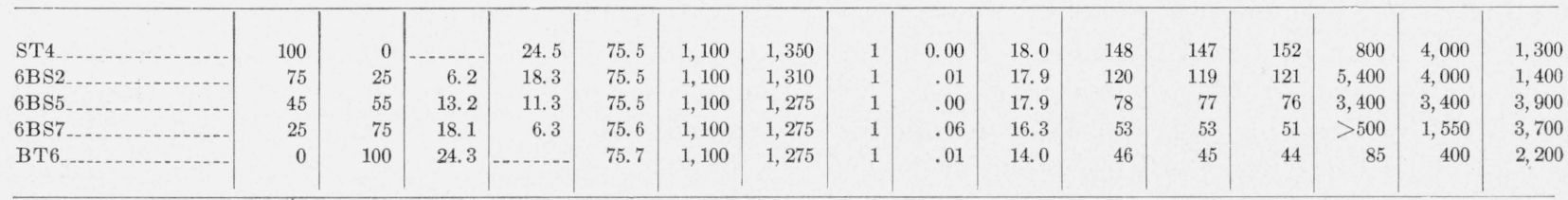

$\mathrm{SrO}: 3.4 \mathrm{TiO}_{2} \mathrm{BaO}: 5 \mathrm{TiO}_{2}$

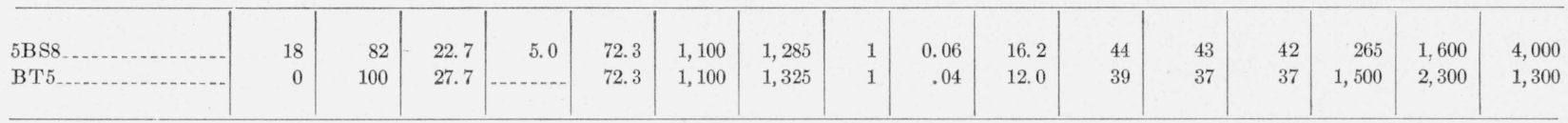

$\mathrm{SrO}: 2.7 \mathrm{TiO}_{2} \quad \mathrm{BaO}: 4 \mathrm{TiO}_{2}$

\begin{tabular}{|c|c|c|c|c|c|c|c|c|c|c|c|c|c|c|c|c|}
\hline BT4 & 0 & 100 & 32.4 & & 67.6 & 1,100 & 1,330 & 1 & .03 & 16. 9 & 34 & 34 & 35 & $>1,600$ & 2,000 & 3,700 \\
\hline
\end{tabular}

$\mathrm{SrO}: 2 \mathrm{TiO}_{2} \quad \mathrm{BaO}: 3 \mathrm{TiO}_{2}$

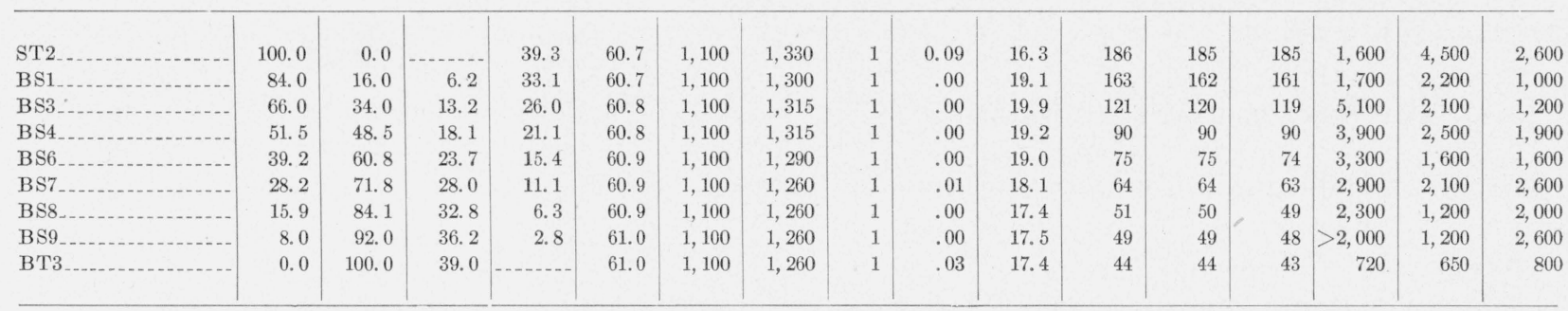

$2 \mathrm{SrO}: 3 \mathrm{TiO}_{2} \quad \mathrm{BaO}: 2.2 \mathrm{TiO}_{2}$

\begin{tabular}{|c|c|c|c|c|c|c|c|c|c|c|c|c|c|c|c|c|}
\hline S2T3.. & 100.0 & 0.0 & ....... & 46.3 & 53.7 & 1,100 & 1,310 & 1 & 0.02 & 16.2 & 200 & 200 & 196 & 450 & 2,600 & 3,500 \\
\hline BS22 ..... & 71.5 & 28.5 & 13.2 & 33.1 & 53.7 & 1,100 & 1,350 & 1 & .02 & 17.9 & 153 & 151 & 149 & 270 & 650 & 1,500 \\
\hline $\mathrm{BS} 23 \ldots$ & 61.0 & 39.0 & 18.1 & 28.2 & 53.7 & 1,100 & 1,360 & 1 & .09 & 17.1 & 153 & 150 & 149 & 560 & 680 & 1,600 \\
\hline BS25 & 49.0 & 51.0 & 23.7 & 22.6 & 53.7 & 1,100 & 1,310 & 1 & .02 & 17.3 & 148 & 147 & 145 & 1,700 & 1,500 & 1,600 \\
\hline BS26 . . . & 39.5 & 60.5 & 28.0 & 18.3 & 53.7 & 1,100 & 1,290 & 1 & .06 & 17.6 & 134 & 133 & 138 & 600 & 550 & 700 \\
\hline BS271_.... & 29.0 & 71.0 & 32.8 & 13.5 & 53.7 & 1,150 & 1,295 & 1 & .00 & 17.6 & 154 & 153 & 153 & 1,200 & 850 & 500 \\
\hline BS279 $\ldots \ldots$ & 20.7 & 79.3 & 36.7 & 9.6 & 53.7 & 1,150 & 1,295 & 1 & .00 & 17.5 & 210 & 205 & 200 & 500 & 480 & 250 \\
\hline BS28 & 12.5 & 87.5 & 40.5 & 5.8 & 53.7 & 1,150 & 1,295 & 1 & .00 & 16.9 & 255 & 255 & 255 & 385 & 170 & 90 \\
\hline BS29 & 6.0 & 94.0 & 43.5 & 2.8 & 53.7 & 1,150 & 1,295 & 1 & .00 & 15.4 & 215 & 215 & 210 & 130 & 100 & 50 \\
\hline $\mathrm{BT} 2.2$ & 0.0 & 100.0 & 46.3 & 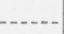 & 53.7 & 1,150 & 1,250 & 1 & .00 & 12.9 & 97 & 95 & 92 & 140 & 75 & 40 \\
\hline
\end{tabular}


TABLE 3.-Composition, heat treatment, absorption, shrinkage, dielectric constant, $K$, and $Q$, of bodies in the system $\mathrm{BaO}-\mathrm{SrO}-\mathrm{TiO}_{2}-$ Continued

\begin{tabular}{|c|c|c|c|c|c|c|c|c|c|c|c|c|c|c|c|c|}
\hline \multirow{3}{*}{$\begin{array}{c}\text { Specimen } \\
\text { designation }\end{array}$} & \multirow{3}{*}{\multicolumn{2}{|c|}{$\begin{array}{l}\text { Proportion of } \\
\text { end members } \\
\text { of join }\end{array}$}} & \multirow{2}{*}{\multicolumn{3}{|c|}{ Composition weight }} & \multicolumn{3}{|c|}{ Heat treatment } & \multirow{3}{*}{$\begin{array}{l}\text { Ab- } \\
\text { sorp- } \\
\text { tion }\end{array}$} & \multirow{3}{*}{$\begin{array}{l}\text { Shrink- } \\
\text { age }\end{array}$} & \multirow{2}{*}{\multicolumn{3}{|c|}{$\begin{array}{l}\text { Delectric constant, } \\
K \text {, at } 25^{\circ} \mathrm{C} \text { and- }\end{array}$}} & \multirow{2}{*}{\multicolumn{3}{|c|}{$\begin{array}{l}\text { Reciprocal, } Q \text {, of power- } \\
\text { factor at } 25^{\circ} \mathrm{C} \text { and- }\end{array}$}} \\
\hline & & & & & & \multirow{2}{*}{$\begin{array}{l}\text { No. } 1 \\
\begin{array}{l}1 \mathrm{hr} \\
\text { at- }\end{array}\end{array}$} & \multicolumn{2}{|c|}{ No. 2} & & & & & & & & \\
\hline & & & $\mathrm{BaO}$ & $\mathrm{SrO}$ & $\mathrm{TiO}_{2}$ & & $\begin{array}{l}\text { Tem- } \\
\text { pera- } \\
\text { ture }\end{array}$ & Time & & & $\begin{array}{l}50 \\
\mathrm{kc} / \mathrm{s}\end{array}$ & $\begin{aligned} 1,000 \\
\mathrm{ke} / \mathrm{s}\end{aligned}$ & $\begin{array}{c}20,000 \\
\mathrm{kc} / \mathrm{s}\end{array}$ & $\begin{array}{l}50 \\
\mathrm{ke} / \mathrm{s}\end{array}$ & $\begin{array}{l}1,000 \\
\mathrm{kc} / \mathrm{s}\end{array}$ & $\begin{array}{c}20,000 \\
\mathrm{kc} / \mathrm{s}\end{array}$ \\
\hline BT2. & $\begin{array}{c}\text { Weight } \\
\text { percent }\end{array}$ & $\begin{array}{r}\text { Weight } \\
\text { percent } \\
100\end{array}$ & $\begin{array}{c}\text { Percent } \\
\quad 49.0\end{array}$ & Percent & $\begin{array}{c}\text { Percent } \\
51.0\end{array}$ & $\begin{array}{c}{ }^{\circ} \mathrm{C} \\
1,100\end{array}$ & $\begin{array}{c}{ }^{\circ} \mathrm{C} \\
1,290\end{array}$ & $\begin{array}{l}h r \\
\quad 1\end{array}$ & $\begin{array}{r}\text { Percent } \\
.02\end{array}$ & $\begin{array}{c}\text { Percent } \\
16.4\end{array}$ & 204 & 200 & 197 & 100 & 70 & 35 \\
\hline \multicolumn{17}{|c|}{$\mathrm{SrO}: \mathrm{TiO}_{2} 2 \mathrm{BaO}: 3 \mathrm{TiO}_{2}$} \\
\hline $\mathrm{B} 2 \mathrm{~S} 5 \ldots$ & 50.0 & 50.0 & 28.1 & 28.2 & 43.7 & 1,100 & 1,290 & 1 & .02 & 17.1 & 460 & 450 & 465 & 1,000 & 800 & 500 \\
\hline $\mathrm{B} 2 \mathrm{~S} 6 \ldots$ & 40.0 & 60.0 & 33.7 & 22.6 & 43.7 & 1,100 & 1,290 & 1 & .03 & 18.0 & 670 & 660 & 645 & 650 & 520 & 325 \\
\hline B2S72 ... & 27.8 & 72.2 & 40.5 & 15.7 & 43.8 & 1,100 & 1,290 & 1 & .03 & 17.8 & - 970 & 950 & 950 & 210 & 190 & 95 \\
\hline B2S83 .. & 17.0 & 83.0 & 46.6 & 9.6 & 43. 9 & 1,100 & 1,290 & 1 & .04 & 17.5 & 1,090 & 1,070 & 1,070 & 110 & 100 & 45 \\
\hline $\mathrm{B} 2 \mathrm{~S} 9 \ldots$ & 10.0 & 90.0 & 50.5 & 5.6 & 43.9 & 1,200 & 1,285 & 2 & .02 & 15.1 & 910 & 895 & 885 & 80 & 80 & 35 \\
\hline B2S95 $\ldots$ & 5.0 & 95.0 & 53.3 & 2.8 & 43.9 & 1,200 & 1,285 & 2 & .00 & 14.7 & 845 & 850 & 850 & 80 & 60 & 30 \\
\hline $\mathrm{B} 2 \mathrm{~T} 3 \ldots$ & 0.0 & 100.0 & 56.1 & & 43.9 & 1,250 & 1,300 & 1 & .01 & 10.8 & 910 & 900 & 890 & 70 & 50 & 25 \\
\hline
\end{tabular}

$\mathrm{SrO}: \mathrm{TiO}_{2} \quad \mathrm{BaO}: \mathrm{TiO}_{2}$

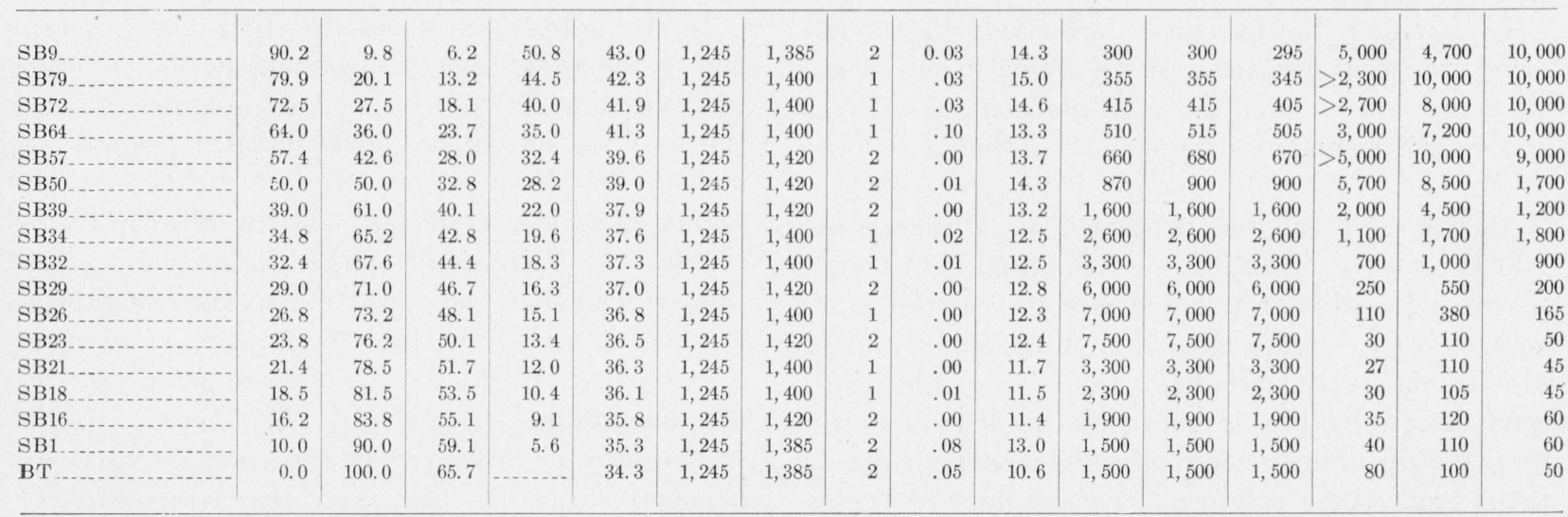

$3 \mathrm{SrO}_{2} \mathrm{TiO}_{2} \mathrm{BaO}: \mathrm{TiO}_{2}$

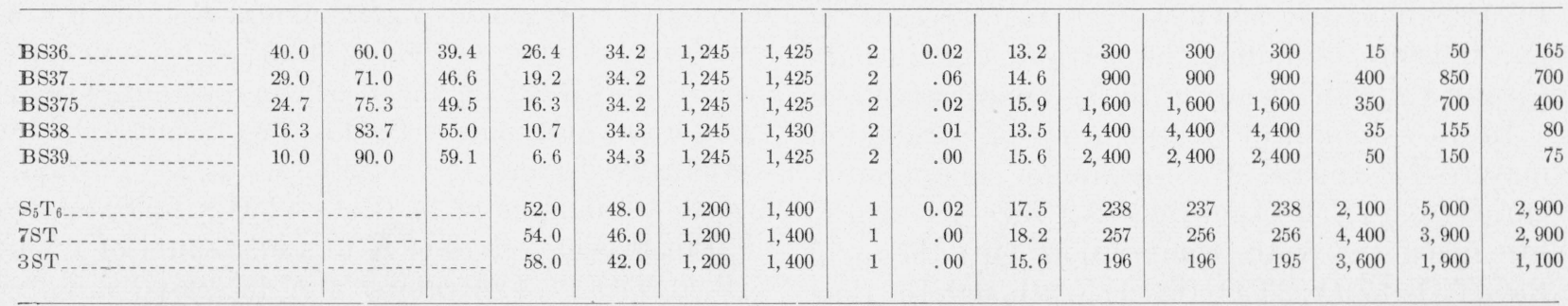


The range in composition of the specimens is illustrated by the diagram in figure $1 .{ }^{4}$ Some of the preparations with compositions indicated by points on the join $3 \mathrm{SrO}: 2 \mathrm{TiO}_{2}-\mathrm{BaO} . \mathrm{TiO}_{2}$ (fig. 1), even though mature, disintegrated after several months storage in porous paper envelopes. As stability of capacitors after prolonged exposure to moisture in the air is important, several specimens of $\mathrm{SrO}^{-\mathrm{TiO}_{2}}$ and those with compositions represented by points on the $\mathrm{BaO} \cdot \mathrm{TiO}_{2}-\mathrm{SrO} \cdot \mathrm{TiO}_{2}$ join were remeasured for $K$ and $Q$ after storage under room conditions for 6 months or more. The values of $K$ and $Q$ had not changed, which indicated that no disintegration had occurred.

Two objects of the heat treatments were (1) to expel the $\mathrm{CO}_{2}$ from the carbonates, and (2) to induce reactions among the remaining oxides so that mature specimens (less than 0.10 percent of absorption) resulted. Although a single heat treatment sufficed for a few preparations, a preliminary heat treatment for calcining most of the batches was necessary. One advantage of calcination was the elimination of difficulties experienced in dry-pressing disks from the extremely finegrained original materials.

In calcining the batches, a relatively high temperature was unsatisfactory. When such temperatures approached those for maturing the disks, the resulting calcines were more difficult to pulverize and to form into compact dry-pressed disks than were the calcines produced at temperatures $100^{\circ} \mathrm{C}$ or more below those of the final heat treatments. Possibly an objection to calcining at relatively low temperatures is the high shrinkage (10 to 20 percent) that occurs on maturing. Such an objection is more than offset by the ability to produce practically nonabsorbent specimens from these calcines, whereas the "high calcined" material was much more difficult to mature. In this study, over 500 disks were made because of the difficulty in finding the narrow range in temperature at which many of the specimens matured.

In the second heat treatment for preparation of mature specimens, the maximum temperature varied from $1,250^{\circ} \mathrm{C}$, for $\mathrm{BaO}: 2.2 \mathrm{TiO}_{2}$, to $14,30^{\circ} \mathrm{C}$ for specimens with compositions in the join $\mathrm{BaO} . \mathrm{TiO}_{2}-3 \mathrm{SrO}: 2 \mathrm{TiO}_{2}$ (fig. 1). Although the time at the maximum temperature of the heat treat-

\footnotetext{
${ }^{4}$ The abbreviated designation of the composition of specimens is evident from a comparison of column 1 with 2 and 3 in table 3 . Thus, $\mathrm{ST}_{12}$ is an abbreviation for SrO : $12 \mathrm{TiO}_{2}$.
}

ments was varied widely, 1 to $30 \mathrm{hr}$, a duration of 1 or $2 \mathrm{hr}$ was sufficient for calcining the batches and maturing the specimens. Approximate maturing temperatures are indicated in figure 2 .

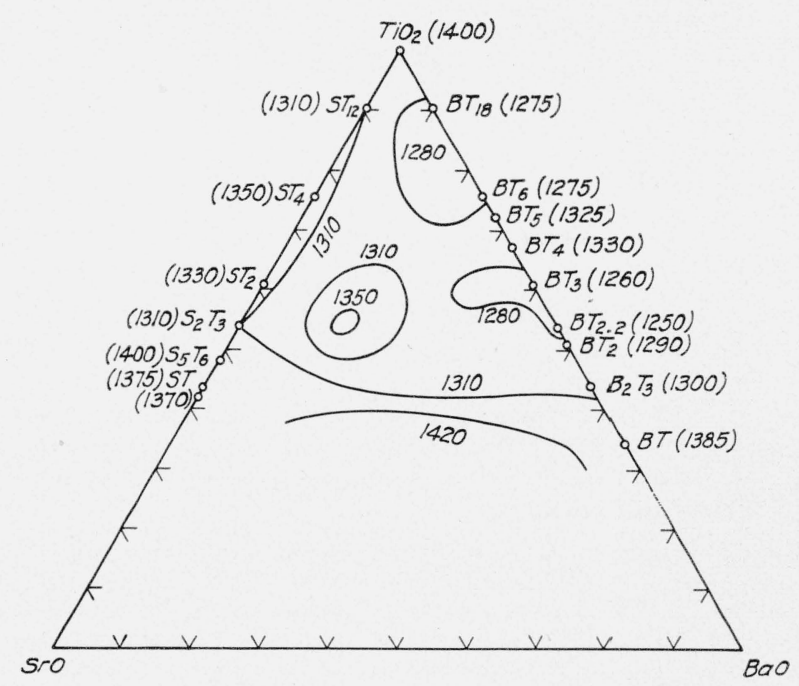

FIGURE 2.-Maturing temperature after sintering treatment. $\mathrm{B}=\mathrm{BaO} ; \mathrm{S}=\mathrm{SrO} ; \mathrm{T}=\mathrm{TiO}_{2}$.

In the determination of the dielectric constant and $Q$, the advantage of specimens with low values of absorption ( 0.1 percent or less) is apparent from the data on specimens TMO (table 1), which are typical for all specimens studied. Although the values of $K$ and $Q$ decrease as the absorption increases, the amount of change in $K$ is much less pronounced than that in $Q$. The values of $K$ were duplicated usually within 1 or 2 percent, but variations of several percent in the values of $Q$ were not uncommon.

The data in table 3 show the effect of variation in composition on the dielectric constant $(K)$. Values of 91 to 98 for mature specimens of titania prepared from grades $T M O, A$, and $R$, table 1 , are within the range of values obtained by other investigators $[1,2]$, for the dielectric constant of such material. Additions of $\mathrm{BaO}$ to $\mathrm{TiO}_{2}$ resulted in (1) gradually decreasing values of $K$ (at $25^{\circ} \mathrm{C}$ ) from 98 to a minimum of $34\left(\mathrm{BaO}: 4 \mathrm{TiO}_{2}\right)$, followed by (2) increasing values of $K$ to a maximum of 1,500 $\left(\mathrm{BaO}: \mathrm{TiO}_{2}\right)$. The values of $K$ increased rapidly when the content of $\mathrm{BaO}$ was increased from 46.3 to 65.7 percent.

By contrast, additions of $\mathrm{SrO}$ to $\mathrm{TiO}_{2}$ caused the values of $K$ to increase gradually from 98 to 260 
$\left(\mathrm{SrO}: \mathrm{TiO}_{2}\right)$. Similarly, increasing values of $K$ were observed in some specimens containing both $\mathrm{BaO}$ and $\mathrm{TiO}_{2}$ when the $\mathrm{SrO}$ content was increased and the concentration of $\mathrm{TiO}_{2}$ maintained constant. This is illustrated by compositions on the joins $\mathrm{BaO}: 18 \mathrm{TiO}_{2}-\mathrm{SrO}: 12 \mathrm{TiO}_{2}, \mathrm{BaO}: 6 \mathrm{TiO}_{2}-\mathrm{SrO}$ : $4 \mathrm{TiO}_{2}$, and $\mathrm{BaO}: 3 \mathrm{TiO}_{2}-\mathrm{SrO}: 2 \mathrm{TiO}_{2}$, as shown in table 3. However, increasing the content of $\mathrm{SrO}$ with the concentrations of $\mathrm{TiO}_{2}$ constant, but less than 61 weight percent, caused the values of $K$ to increase rapidly to a peak and then to decrease. This is illustrated by compositions on the joins $\mathrm{BaO}: 2.2 \mathrm{TiO}_{2}-2 \mathrm{SrO}: 3 \mathrm{TiO}_{2}, 2 \mathrm{BaO}: 3 \mathrm{TiO}_{2}-\mathrm{SrO}: \mathrm{TiO}_{2}$, and $\mathrm{BaO}: \mathrm{TiO}_{2}-\mathrm{SrO}: \mathrm{TiO}_{2}$. At $25^{\circ} \mathrm{C}$, changes in the dielectric constant ranging from 1,000 to 3,000 resulted from small alterations in the compositions in the join $\mathrm{BaO}: \mathrm{TiO}_{2}-\mathrm{SrO}: \mathrm{TiO}_{2}$, as shown in table 3 .

The dielectric constant $(K)$, measured at 1 $m c / s$, was affected also by the temperature of the specimens, as indicated by the data in table 4 . The values for $30^{\circ}, 50^{\circ}$, and $80^{\circ} \mathrm{C}$, can be found by interpolation for most of the specimens. The smallest variations in $K$ were observed for specimens with binary compositions in the range 61.0 to 75.6 weight percent of $\mathrm{TiO}_{2}$ and 24.4 to 39.0 weight percent of $\mathrm{BaO}$, whereas the largest variations in $K$ were found for specimens that had compositions represented by points in the join $\mathrm{BaO}: \mathrm{TiO}_{2}-\mathrm{SrO}: \mathrm{TiO}_{2}$.

TABLE 4.-Dielectric constant, at $1 \mathrm{mc} / \mathrm{s}$, from $-60^{\circ}$ to $+85^{\circ} \mathrm{C}$, and temperature coefficient of dielectric constant at $0^{\circ} \mathrm{C}$

\begin{tabular}{|c|c|c|c|c|c|c|c|c|c|c|c|c|c|c|}
\hline \multirow{2}{*}{ Specimen a designation } & \multicolumn{13}{|c|}{ Values of $K$ at $\left({ }^{\circ} \mathrm{C}\right)$} & \multirow{2}{*}{$\begin{array}{c}\text { Tempera- } \\
\text { ture co- } \\
\text { efficient } \\
\text { of } K \text { at } \\
0^{\circ} \mathrm{C}\end{array}$} \\
\hline & $-60^{\circ}$ & $-50^{\circ}$ & $-40^{\circ}$ & $-30^{\circ}$ & $-20^{\circ}$ & $-10^{\circ}$ & $0^{\circ}$ & $+10^{\circ}$ & $+20^{\circ}$ & $+40^{\circ}$ & $+60^{\circ}$ & $+70^{\circ}$ & $+85^{\circ}$ & \\
\hline $\mathrm{TiO}_{2}(\mathrm{~A})^{\mathrm{b}}$ & 105.7 & 104.5 & 103.3 & 102.3 & 101. 2 & 100.3 & 99.5 & 98.7 & 97.9 & 96.4 & 95.1 & 94.3 & 93.3 & $\begin{array}{l}p p m \\
\quad-850\end{array}$ \\
\hline $\mathrm{TiO}_{2}(\mathrm{R}){ }^{\mathrm{O}}$ & 106.2 & 104.9 & 103.6 & 102.5 & 101.5 & 100.4 & 99.3 & 98.6 & 98.0 & 96.8 & 95.5 & 94.0 & 93.6 & ....... \\
\hline ST12.. & 131 & 128 & 126 & 123.5 & 121.5 & 120 & 118 & 116.5 & 115 & 112.5 & 110 & 109 & 107 & -1350 \\
\hline $18 \mathrm{BS} 6$ & 90.7 & 89.5 & 88.4 & 87.5 & 86.6 & 85.8 & 85.0 & 84.4 & 83.7 & 82.7 & 81.6 & 81.2 & 80.4 & -830 \\
\hline BT18_........ & 80.5 & 79. 7 & 78.9 & 78.3 & 77.6 & 77.0 & 76.5 & 76.0 & 75.4 & 74.3 & 73.4 & 73.0 & 72.5 & -750 \\
\hline ST4 & 186 & 180 & 174 & 168 & 163 & 159 & 155 & 152 & 149 & 143 & 138 & 135 & 131 & -2500 \\
\hline $6 \mathrm{BS} 2 \ldots$ & 152 & 147 & 142 & 138 & 135 & 132 & 128 & 126 & 123 & 118 & 114 & 112 & 110 & -2200 \\
\hline $6 \mathrm{BS} 5 \ldots$ & 88.5 & 86.4 & 84.7 & 83.4 & 82.3 & 81.2 & 80.2 & 79.2 & 78.0 & 76.2 & 74.8 & 74.2 & 73.5 & -1300 \\
\hline $6 \mathrm{BS} 7 \ldots$ & 56.3 & 55.8 & 55.4 & 55.0 & 54.6 & 54.3 & 54.0 & 53.7 & 53.3 & 52.5 & 52.0 & 51.7 & 51.3 & -650 \\
\hline BT6... & 46. 5 & 46.3 & 46.2 & 46.0 & 45.8 & 45.6 & 45.4 & 45.3 & 45.1 & 44.9 & 44. 7 & 44.6 & 44.5 & -370 \\
\hline $5 \mathrm{BS} 8$ & 43.1 & 43.0 & 42.9 & 42.8 & 42.8 & 42.7 & 42.7 & 42.6 & .42 .5 & 42.3 & 42.3 & 42.2 & 42.2 & -200 \\
\hline BT5 ... & 36.7 & 36. 7 & 36.7 & 36.7 & 36.7 & 36.7 & 36.7 & 36.7 & 36.7 & 36.7 & 36.7 & 36.7 & 36.7 & 0 \\
\hline $4 \mathrm{BS} 8$ & 44.0 & 43. 7 & 43.5 & 43.3 & 43.1 & 42.9 & 42.7 & $42: 6$ & 42.5 & 42.4 & 42.3 & 42.3 & 42.2 & -380 \\
\hline $4 \mathrm{BS} 9$ & 36.8 & 36.8 & 36.8 & 36.8 & 36.9 & 36.9 & 36.9 & 37.0 & 37.0 & 37.2 & 37.3 & 37.3 & 37.4 & +100 \\
\hline BT4 & 33.0 & 33.1 & 33. 2 & 33.3 & 33.4 & 33.5 & 33.6 & 33.7 & 33.7 & 33.9 & 34.0 & 34.0 & 34.0 & +260 \\
\hline ST2. & 255 & 244 & 233 & 224 & 214 & 206 & 200 & 195 & 189 & 180 & 171 & 167 & 162 & -3000 \\
\hline BS1 ... & 220 & 207 & 197 & 190 & 183 & 178 & 173 & 168 & 164 & 156 & 149 & 146 & 141 & -2300 \\
\hline BS3 .... & 160 & 151 & 145 & 140 & 135 & 132 & 128 & 126 & 123 & 118 & 114 & 112 & 109 & -2400 \\
\hline BS4 & 112 & 108 & 105 & 103 & 100 & 98 & 96 & 94 & 92 & 89 & 86 & 84 & 82 & -2200 \\
\hline BS6 . . & 92.8 & 89.5 & 86.7 & 84.5 & 82.0 & 80.0 & 78.5 & 77.0 & 76.0 & 73.5 & 71.2 & 70.3 & 69.0 & -1900 \\
\hline $\mathrm{BS} 7$ & 78.9 & 76.3 & 74.0 & 72.0 & 70.2 & 68.6 & 67.4 & 66.2 & 65.2 & 63.4 & 61.8 & 61.2 & 60.3 & -1800 \\
\hline BS8 $\ldots$ & 55.9 & 54.8 & 53.9 & 53.2 & 52.6 & 52.1 & 51.8 & 51.4 & 51.1 & 50.4 & 50.0 & 49.8 & 49.4 & -730 \\
\hline BS9... & 52.4 & 52.0 & 51.5 & 51.1 & 50.8 & 50.4 & 50.1 & 49.8 & 49.5 & 49.0 & 48.6 & 48.4 & 48.1 & -640 \\
\hline BT3 & 44.6 & 44.5 & 44.5 & 44.4 & 44.3 & 44.3 & 44. 2 & 44.1 & 44.1 & 43.9 & 43.8 & 43.8 & 43.7 & -160 \\
\hline S2T3 .. & 274 & 262 & 250 & 240 & 230 & 221 & 213 & 207 & 202 & 193 & 184 & 179 & 173 & -3200 \\
\hline BS22 - & 210 & 201 & 191 & 183 & 175 & 168 & 162 & 158 & 154 & 146 & 139 & 136 & 132 & -3100 \\
\hline BS23 ... & 230 & 216 & 203 & 192 & 183 & 175 & 167 & 161 & 155 & 144 & 134 & 131 & 126 & -4100 \\
\hline BS25 ... & 241 & 220 & 202 & 190 & 179 & 170 & 162 & 156 & 150 & 140 & 131 & 128 & 122 & -4400 \\
\hline BS26 $\ldots$ & 216 & 198 & 182 & 170 & 159 & 151 & 145 & 140 & 135 & 127 & 118 & 115 & 111 & -4100 \\
\hline BS271 $\ldots$ & 303 & 277 & 253 & 230 & 208 & 194 & 181 & 170 & 160 & 145 & 132 & 127 & 123 & -5900 \\
\hline BS279 $\ldots$ & 288 & 292 & 296 & 297 & 293 & 284 & 269 & 246 & 226 & 187 & 162 & 152 & 141 & (n) \\
\hline BS28 ... & 227 & 234 & 239 & 243 & 249 & 252 & 254 & 256 & 256 & 247 & 226 & 214 & 190 & - \\
\hline BS29 .......... & 174 & 181 & 185 & 192 & 196 & 198 & 201 & 204 & 207 & 216 & 225 & 231 & 230 & (n) \\
\hline BT2.2 & 85.2 & 86.6 & 88.0 & 89.3 & 90.8 & 92.0 & 93.2 & 94.1 & 95.1 & 96.8 & 98.5 & 99.5 & 101 & +1200 \\
\hline BT2 ... & 163 & 168 & 173 & 177 & 182 & 187 & $192 *$ & 196 & 200 & 204 & 210 & 214 & 221 & +2600 \\
\hline
\end{tabular}

See footnotes at end of table. 
TABLE 4.-Dielectric constant, at $1 \mathrm{mc} / \mathrm{s}$, from $-60^{\circ}$ to $+85^{\circ} \mathrm{C}$, and temperature coefficient of dielectric constant at $0^{\circ} \mathrm{C}-\mathrm{Con}$.

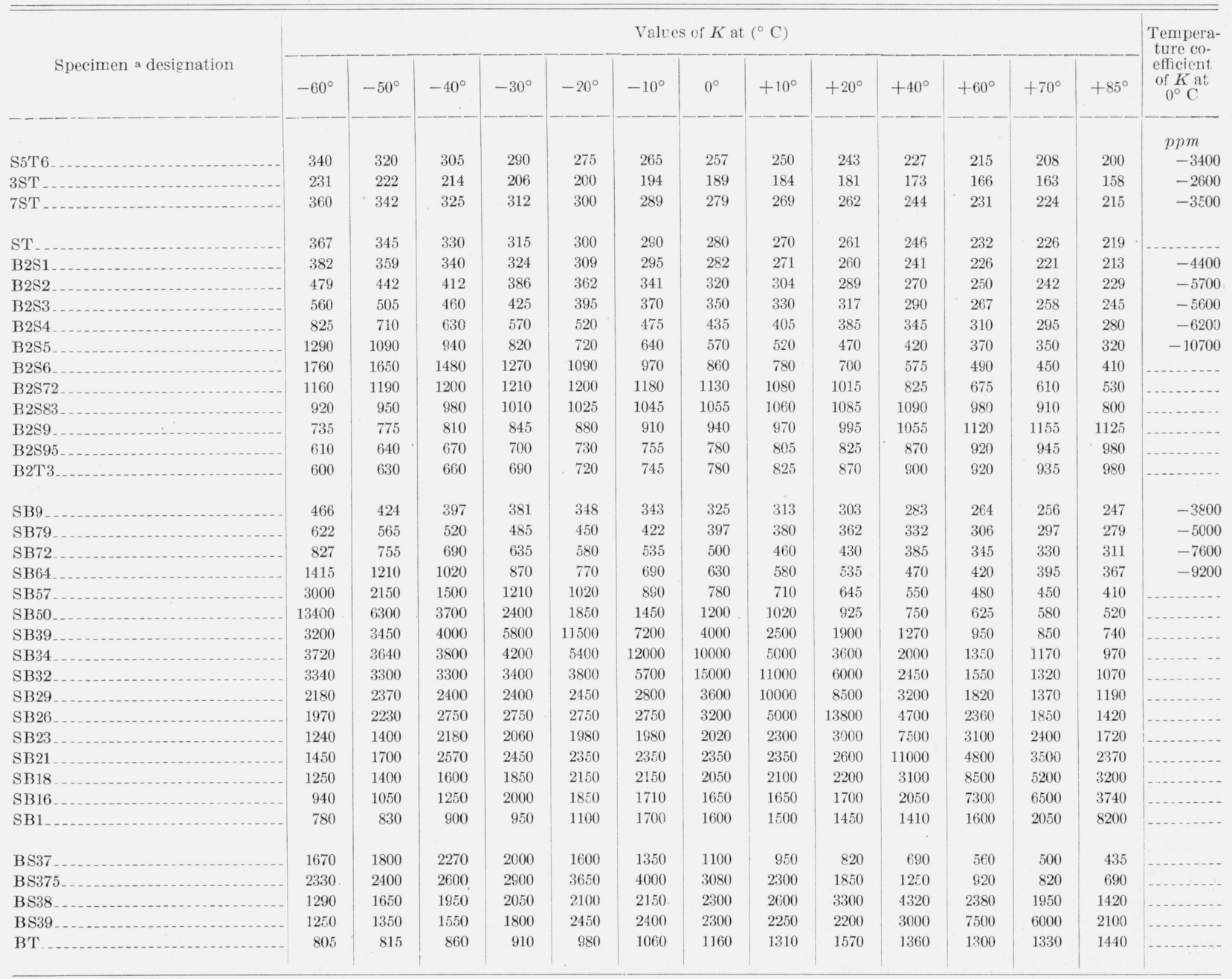

a For compositions, see tables 1 and 3.

b Grade designation (table 1).

The effect of temperature, over the range $-60^{\circ}$ to $+85^{\circ} \mathrm{C}$, upon the dielectric constant of specimens in the system $\mathrm{BaO}-\mathrm{TiO}_{2}$ is illustrated by figure 3 . In diagram $A$ the negative temperature coefficient of $K$ for titanium dioxide is indicated by the curve $\mathrm{TiO}_{2}$. It is seen that increasing the content of $\mathrm{BaO}$ in the specimens (to approximately 28 weight percent), as in $\mathrm{BaO}: 5 \mathrm{TiO}_{2}$, resulted in a reduction of the negative temperature coefficient. Attention is directed to the specimen containing 27.7 percent of $\mathrm{BaO}$, because the dielectric constant remained unaltered by changes in temperature within the range $-60^{\circ}$ to $+85^{\circ} \mathrm{C}$, as shown by the curve $\mathrm{BaO}: 5 \mathrm{TiO}_{2}$. Certain irregularities in the dielectric constant appeared when the concentration of $\mathrm{BaO}$ was more than 28 weight percent. Specimen $\mathrm{BaO}: 4 \mathrm{TiO}_{2}$ (32.4 percent of $\mathrm{BaO}$ ) had a slightly positive temperature coefficient of $K$ as well as the lowest observed value for $K$, as shown by the curve $\mathrm{BaO}: 4 \mathrm{TiO}_{2}$ in diagram $A$, figure 3 . A further increase of 6.6 percent of $\mathrm{BaO}$ resulted not only in a higher value of $K$ but also in a slightly negative temperature coefficient, as illustrated by curve $\mathrm{BaO}: 3 \mathrm{TiO}_{2}$ in diagram $B$. As the concentration of $\mathrm{BaO}$ increased within the range 39 to 65.7 weight percent $\left(\mathrm{BaO}: 3 \mathrm{TiO}_{2}\right.$ to $\left.\mathrm{BaO} . \mathrm{TiO}_{2}\right)$, the dielectric constant of the specimens exhibited more pronounced changes with temperature as well as increased values of $K$, as illustrated by 

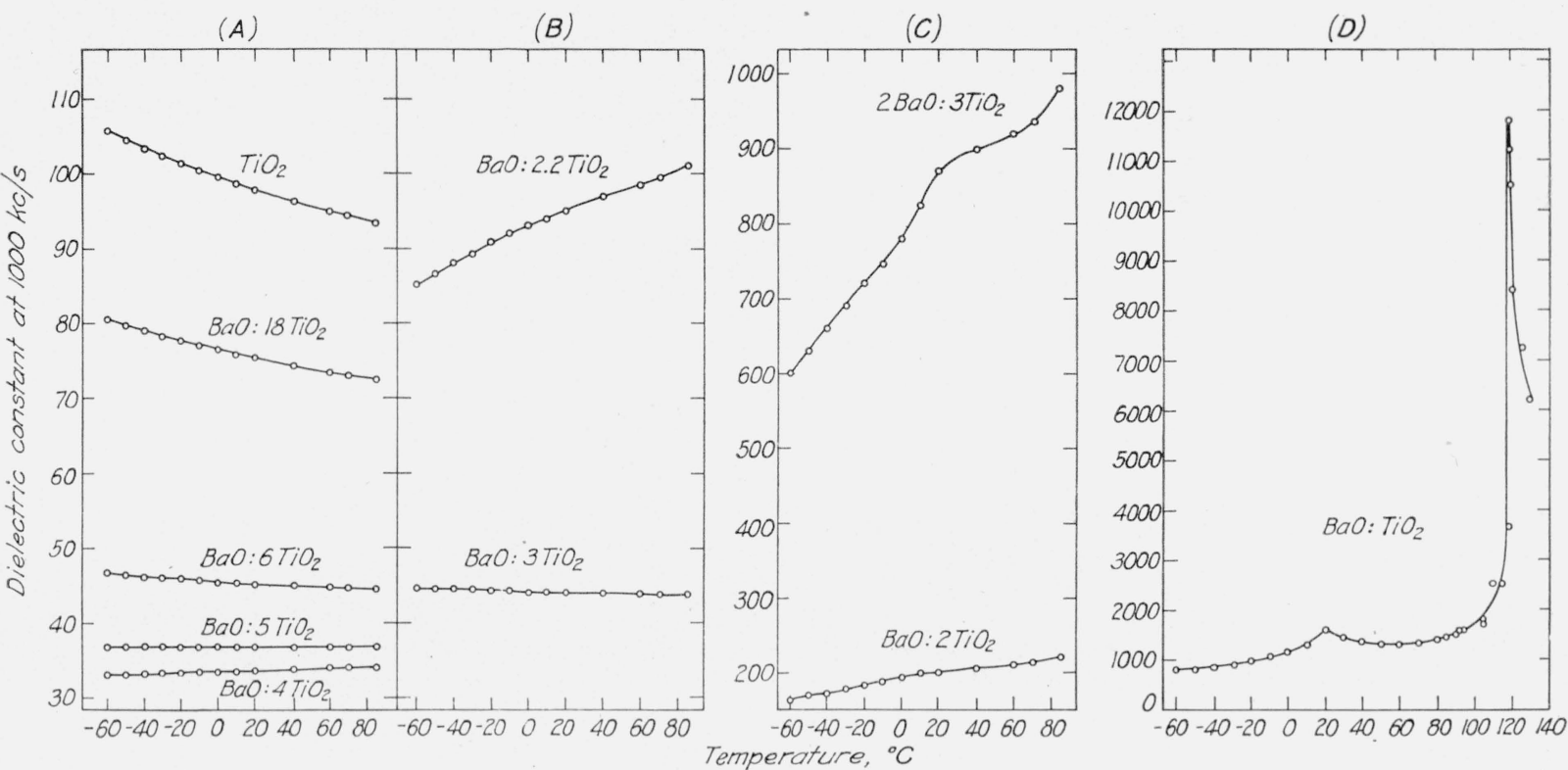

FIGURE 3.-Variation of dielectric constant with temperature, at 1,000 kc/s, for specimens with compositions in the binary system, $\mathrm{TiO}_{2}-\mathrm{BaTiO}_{3}$.

diagrams $B, C$, and $D$ (fig. 3). It should be noted that the scales were altered in the ordinate of diagrams $C$ and $D$, because of the high values of $K$.

Other investigators [1, 2] have found considerable variation in dielectric constant with changes in temperature of specimens prepared from $\mathrm{BaO}^{-\mathrm{TiO}_{2}}$. In the present study, diagram $D$, figure 3 , shows the character of the dielectricconstant-temperature curve for these specimens. Although a peak value of $11,800 K$ was observed at $118^{\circ} \mathrm{C}$, variations of as much as 1,000 or more in the values of $K$ were caused by small changes in temperature within the range of $110^{\circ}$ to $125^{\circ} \mathrm{C}$. The rapid variation of $K$ with temperature occurs at a reversible change in crystal structure from pseudocubic to the cubic perovskite structure [2], indicated by X-ray studies.

Additions of $\mathrm{SrO}$ to specimens containing $\mathrm{BaO}$ and $\mathrm{TiO}_{2}$, denoted by the joins in the diagram of figure 1 , resulted in negative temperature coefficient of $K$ for most of the specimens, as shown in the last column of table 4 . Coefficients were not computed for all the specimens because of the irregularities in the curves of dielectric constant versus temperature.

The portion of the ternary diagram in which peaks were observed in the dielectric-constanttemperature curves is indicated in figure 4. These peaks were a maximum for specimens with com- positions indicated by points in the join $\mathrm{BaO}^{-\mathrm{TiO}_{2}-}$ $\mathrm{SrO}^{\mathrm{T}} \mathrm{TiO}_{2}$. The curve with a peak at $41^{\circ} \mathrm{C}$ (fig. 5) for one of these specimens, SB21, resembles the curve for $\mathrm{BaO} \mathrm{TiO}_{2}$ (fig. $3, D$ ). It was found that increasing the content of $\mathrm{SrO}$ in this series of compositions on the $\mathrm{SrO} \cdot \mathrm{TiO}_{2}-\mathrm{BaO}$. TiO ${ }_{2}$ join resulted in decreasing the temperature at which the peak in dielectric constant occurred (fig. 6). Extrapolation of the curve indicates a peak for

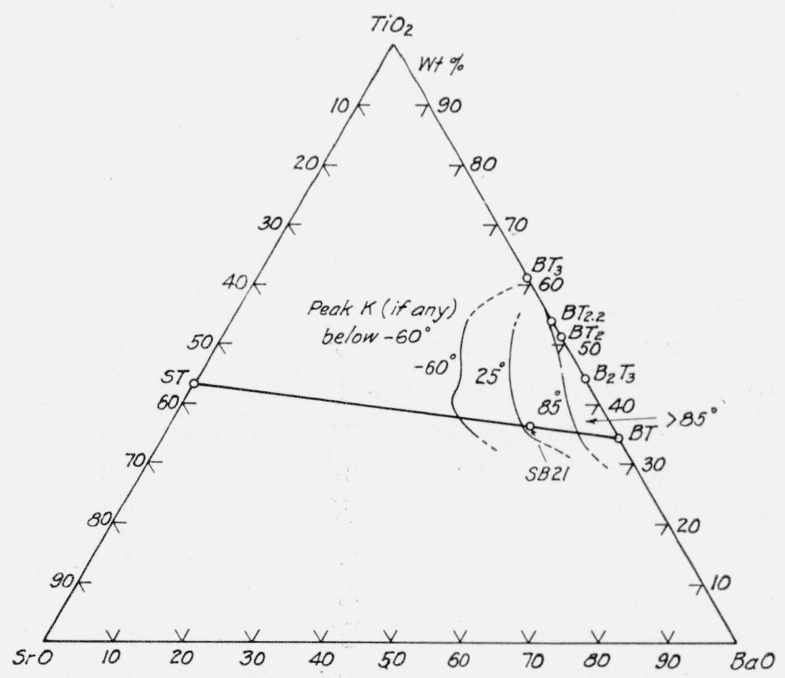

FiguRE 4.-Relation between the temperature at which the peak dielcetric constant occurs and compositions in the $\mathrm{BaO}-\mathrm{SrO}-\mathrm{TiO}_{2}$ system. $\mathrm{B}=\mathrm{BaO} ; \mathrm{S}=\mathrm{SrO} ; \mathrm{T}=\mathrm{TiO}_{2}$. 
$\mathrm{SrTiO}_{3}$ at a temperature of approximately $-240^{\circ}$ C. Similar data by other investigators indicate that this peak is near $-260^{\circ} \mathrm{C}[7]$.

Figures 7,8 , and 9 show the lines of constant values of $K$ at $-60^{\circ}, 0^{\circ}$, and $+60^{\circ} \mathrm{C}$ with variations in composition over a portion of the ternary system $\mathrm{BaO}-\mathrm{SrO}-\mathrm{TiO}_{2}$. These diagrams indicate

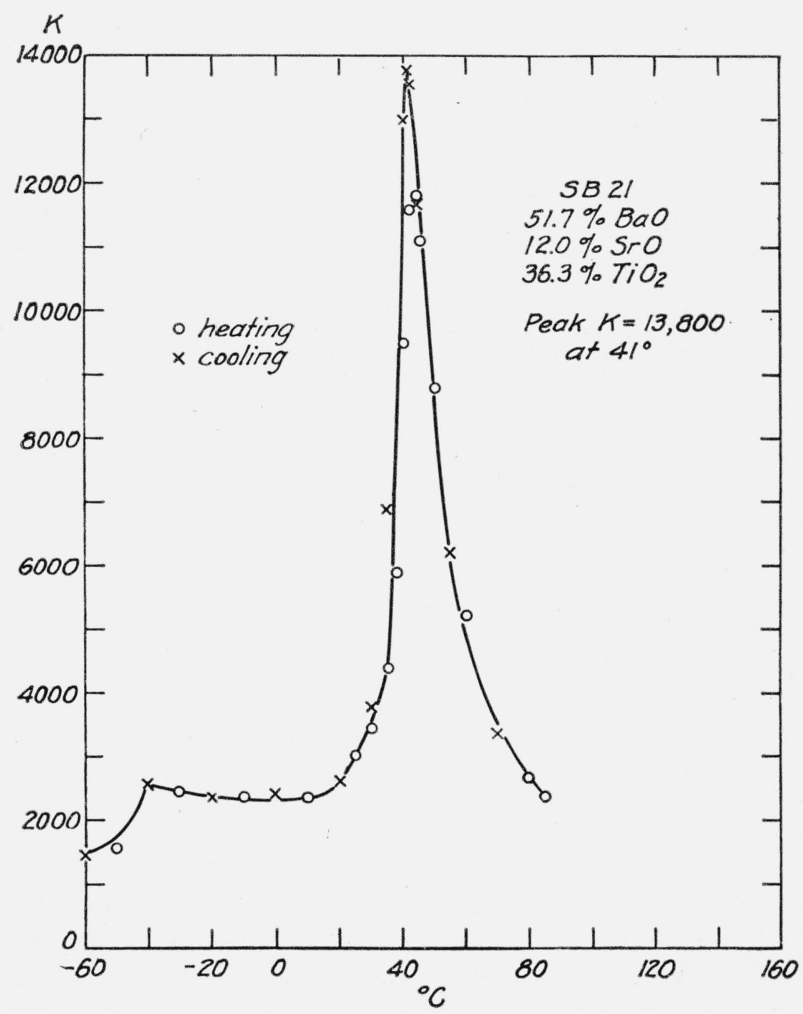

FIGURE 5.-V Variation of diclectric constant with temperature, at 1,000 kc/s, for specimen SB21 with composition on the $\mathrm{SrTiO}_{3}-\mathrm{BaTiO}_{3}$ join.

the changes in the values of $K$ that result from simultaneous alterations of both temperature and composition.

Despite the relatively low dielectric constant (37) of specimens having the composition $\mathrm{BaO}$ : $5 \mathrm{TiO}_{2}$, the zero temperature coefficient of $K$ is noteworthy. It was found, however, that an addition of 5 percent of $\mathrm{SrO}$ to this composition led to a negative coefficient, as in specimens 5BS8 (table 4). Specimens 4BS8 also had a low negative coefficient, whereas $4 \mathrm{BS} 9$ had a positive coefficient. Thus, specimens having zero temperature coefficient of $K$ are limited in composition to a small region in the vicinity of the composition indicated by the point BT5, figure 1. For some

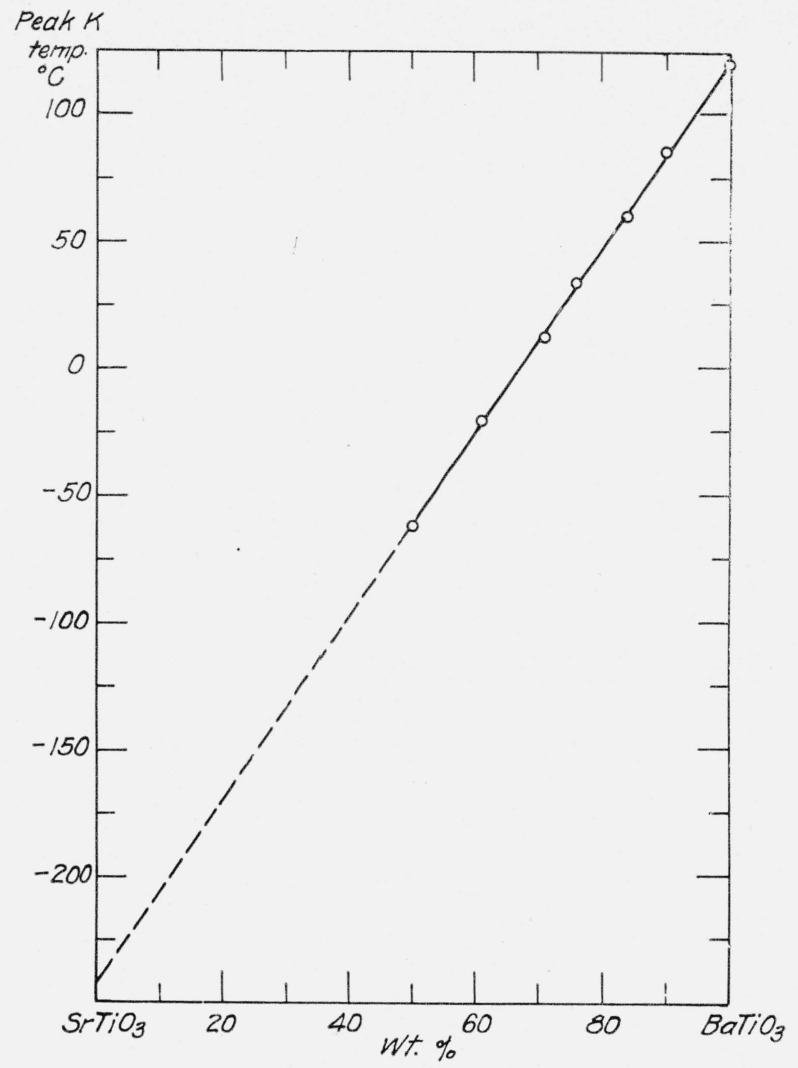

FIGURE 6.-Variation of the temperature at which the peak dielectric constant occurs with composition on the $\mathrm{SrTiO}_{3}$ $\mathrm{BaTiO}_{3}$ join.

uses, such as delay lines, the dielectric with zero temperature coefficient is desirable.

The dielectric constant was not affected by variations in frequency within the range 50 to $20,000 \mathrm{kc} / \mathrm{s}$. It is believed that the slight differences in observed values of $K$ are within experimental error.

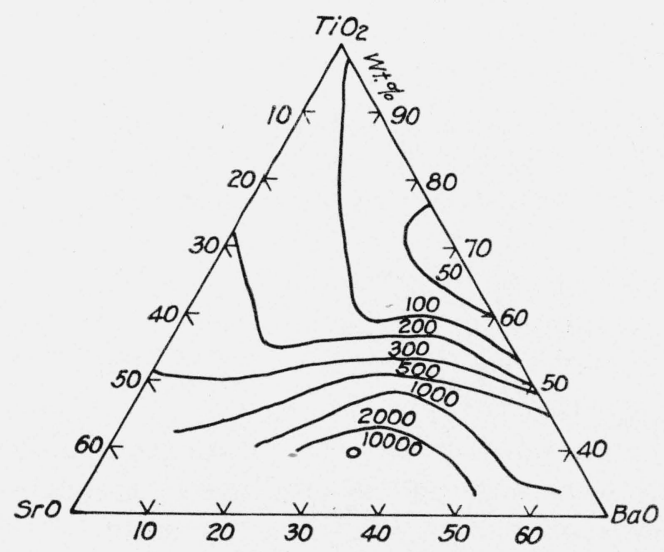

Figure 7.-Constant $K$ with varying compositions at $-60^{\circ} \mathrm{C}$. 
The variation in values of $Q$ caused by alterations in composition and frequency is shown by the data in table 3. Although most of the specimens had relatively high values of $Q$ (400 to

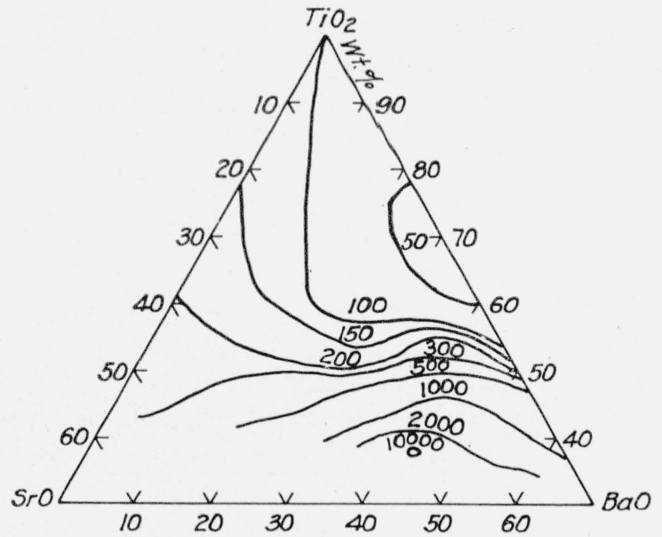

FIGURE 8.-Constant $K$ with varying compositions at $O^{\circ} \mathrm{C}$.

$10,000)$, those containing more than 46.0 percent of $\mathrm{BaO}$ exhibited low values of from 50 to 100 . With specimens having a constant and relatively low content of $\mathrm{TiO}_{2}$, an increase in the concentra-

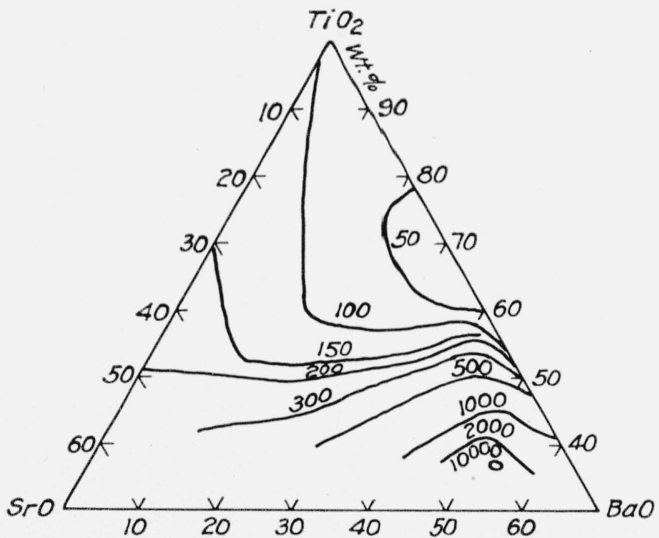

FIg URE 9.-Constant $K$ with varying compositions $c t+60^{\circ} \mathrm{C}$.

tion of $\mathrm{SrO}$ was accompanied by increased values of $Q$, as illustrated in table 3 . As an absorption of over 0.01 percent was attended by a lower value of $Q$, some of the specimens with absorptions over 0.01 percent probably exhibited values of $Q$ lower than the best obtainable.
TABLE 5.-Dielectric constant $K$, and $Q$, the reciprocal of the power factcr, at $25^{\circ} \mathrm{C}$ and $1 \mathrm{mc} / \mathrm{s}$ and $3,000 \mathrm{mc} / \mathrm{s}$

\begin{tabular}{l|r|r|r|r}
\hline \hline Specimen designation & $K$ at $1 \mathrm{mc} / \mathrm{s}$ & $Q$ at $1 \mathrm{mc} / \mathrm{s}$ & $\begin{array}{c}K \text { at } 3,000 \\
\mathrm{me} / \mathrm{s}\end{array}$ & $\begin{array}{c}Q \text { at } 3,000 \\
\mathrm{me} / \mathrm{s}\end{array}$ \\
\hline & & & & 460 \\
$\mathrm{BaO}: 3 \mathrm{TiO}_{2}$ & 43 & 3,600 & 42 & 520 \\
$\mathrm{BS} 6 \ldots$ & 2,400 & 76 & 310 \\
$\mathrm{BS} 7 \ldots$ & 71 & 1,000 & 74 &
\end{tabular}

The data in table 3 show little correlation of $Q$ with frequency. In some instances, a specimen had low $Q$ at $50 \mathrm{kc} / \mathrm{s}$ and fairly high $Q$ at 20,000 $\mathrm{kc} / \mathrm{s}$, for example, BT6. Often a duplicate specimen exhibited a high $Q$ at all frequencies. As an example of the variation in $Q$ values of specimens receiving the same preparation and heat treatments, the data in table 6 are given. Although the variation in the dielectric constant is not large, the $Q$ values show a very large variation. However, the specimen with the highest absorption has the lower $Q$ value. The reason for these differences is not apparent, but it may be connected with a number of factors, such as the size of crystals and pores, as well as the state of oxidation of the titanium compounds.

Variations in the properties of specimens of the same composition, SB50, which received different heat-treatments, are given in table 7 . These specimens have a fairly large maturing range with small variation in dielectric constant. Similar data could be given for most of the other compositions of low $\mathrm{BaO}$ content.

TABle 6.-Properties oj specimens of $\mathrm{SrTiO}_{3}$, sintered for $1 \mathrm{hr}$ at $1,245^{\circ} \mathrm{C}$ and heated at $1,350^{\circ} \mathrm{C}$ for $1 \mathrm{hr}$

\begin{tabular}{|c|c|c|c|c|c|c|c|}
\hline \multirow{2}{*}{ Absorption } & \multirow{2}{*}{$\begin{array}{c}\text { Shrink- } \\
\text { age }\end{array}$} & \multicolumn{3}{|c|}{$\begin{array}{c}\text { Dielectric constant }(K) \text {, } \\
25^{\circ} \mathrm{C}\end{array}$} & \multicolumn{3}{|c|}{$\begin{array}{l}\text { Reciprocal }(Q) \text { of power } \\
\text { factor, } 25^{\circ} \mathrm{C}\end{array}$} \\
\hline & & $50 \mathrm{kc} / \mathrm{s}$ & $\begin{array}{l}1,000 \\
\mathrm{ke} / \mathrm{s}\end{array}$ & $\begin{array}{c}20,000 \\
\mathrm{kc} / \mathrm{s}\end{array}$ & $50 \mathrm{ke} / \mathrm{s}$ & $\begin{array}{l}1,000 \\
\mathrm{kc} / \mathrm{s}\end{array}$ & $\begin{array}{c}20,000 \\
\mathrm{kc} / \mathrm{s}\end{array}$ \\
\hline $\begin{array}{r}\text { Percent } \\
0.11\end{array}$ & $\begin{array}{c}\text { Percent } \\
14.8\end{array}$ & 268 & 264 & 260 & 450 & 1,350 & 3,500 \\
\hline $0.06 \ldots \ldots$ & 15.0 & 249 & 246 & 243 & 2,100 & 3,200 & 4,800 \\
\hline $0.05 \ldots$ & 15.0 & 258 & 254 & 249 & 900 & 4,000 & 8,000 \\
\hline $0.05 \ldots$ & 14.8 & 253 & 250 & 245 & 1,000 & 1,350 & 4,500 \\
\hline $0.01 \ldots$ & 15.2 & 260 & 260 & 260 & 5,500 & 8,000 & 10,000 \\
\hline $0.00 \ldots \ldots$ & 15.0 & 252 & 249 & 245 & 900 & 4,000 & 8,000 \\
\hline
\end{tabular}


TABLE 7.-Properties of specimens of SB50, sintered at $1,245^{\circ} \mathrm{C}$ for $1 \mathrm{hr}$, and heated at $1,350^{\circ} \mathrm{C}, 1,385^{\circ} \mathrm{C}$, and $1,420^{\circ} \mathrm{C}$ for $2 \mathrm{hr}$

\begin{tabular}{|c|c|c|c|c|c|c|c|c|}
\hline \multirow{2}{*}{$\begin{array}{l}\text { Heated } \\
2 \mathrm{hr}\end{array}$} & \multirow{2}{*}{$\begin{array}{l}\text { Absorp- } \\
\text { tion }\end{array}$} & \multirow{2}{*}{ Shrink- } & \multicolumn{3}{|c|}{$\begin{array}{l}\text { Dielectric constant }(K) \text {, } \\
\qquad 25^{\circ} \mathrm{C}\end{array}$} & \multicolumn{3}{|c|}{$\begin{array}{l}\text { Reciprocal }(O) \text { of power } \\
\text { factor, } 25^{\circ} \mathrm{C}\end{array}$} \\
\hline & & & $50 \mathrm{kc} / \mathrm{s}$ & $\begin{array}{l}1,000 \\
\mathrm{kc} / \mathrm{s}\end{array}$ & $\begin{array}{c}20,000 \\
\mathrm{kc} / \mathrm{s}\end{array}$ & $50 \mathrm{kc} / \mathrm{s}$ & $\begin{array}{l}1,000 \\
\mathrm{ke} / \mathrm{s}\end{array}$ & $\begin{array}{c}20,000 \\
\mathrm{kc} / \mathrm{s}\end{array}$ \\
\hline${ }^{\circ} \mathrm{C}$ & Percent & Percent & & & & & & \\
\hline $1,350_{-}$ & 0.02 & 14.3 & 870 & 900 & 890 & 2,900 & 6,100 & 1,600 \\
\hline $1,350_{-}$ & .0 .5 & 14.3 & 870 & 890 & 900 & 3,400 & 5,800 & 300 \\
\hline $1,385 \ldots$ & .05 & 14.2 & 870 & 870 & 880 & 5,400 & 7,000 & 1,600 \\
\hline $1,385 \ldots$ & .07 & 14.3 & 870 & 870 & 890 & 5,700 & 7,500 & 1,400 \\
\hline $1,420_{-}$ & .01 & 14.3 & 860 & 860 & 870 & 2,800 & $8,500^{\circ}$ & 1,700 \\
\hline $1,420 \ldots$ & .02 & 14.3 & 870 & 860 & 870 & 2,300 & 7,500 & 1,200 \\
\hline
\end{tabular}

In the specimens having a high $\mathrm{BaO}$ content, and low $Q$ values, the variations in the dielectric constant and the $Q$ values are more nearly equal, as shown by the data in table 8 . In general, for specimens having a low $\mathrm{BaO}$ content, the variations in the dielectric constant, for well vitrified samples, are much less than the variations in the $Q$ values, although for specimens of high $\mathrm{BaO}$ content, and low $Q$ values, these variations are more nearly equal.

TABLE 8.-Variations in properties of some specimens containing over 40 percent of $\mathrm{BaO}$

\begin{tabular}{|c|c|c|c|c|c|c|c|c|c|c|c|}
\hline \multirow{2}{*}{$\begin{array}{c}\text { Speci- } \\
\text { men } \\
\text { desig- } \\
\text { nation }\end{array}$} & \multicolumn{4}{|c|}{ Heat treatments } & \multirow{2}{*}{$\begin{array}{l}\text { Ab- } \\
\text { sorp- } \\
\text { tion }\end{array}$} & \multicolumn{3}{|c|}{$\begin{array}{l}\text { Dielectric con- } \\
\text { stant }(K), 25^{\circ} \mathrm{C}\end{array}$} & \multicolumn{3}{|c|}{$\begin{array}{l}\text { Reciprocal }(O) \\
\text { of power factor }\end{array}$} \\
\hline & $\begin{array}{l}\text { Tem- } \\
\text { pera- } \\
\text { ture }\end{array}$ & Time & $\begin{array}{l}\text { Tem- } \\
\text { pera- } \\
\text { ture }\end{array}$ & Time & & $\begin{array}{c}50 \\
\mathrm{kc} / \mathrm{s}\end{array}$ & $\begin{array}{l}1,000 \\
\mathrm{k} e \mathrm{~s}\end{array}$ & $\begin{array}{c}20,000 \\
\mathrm{kc} / \mathrm{s}\end{array}$ & $\begin{array}{c}50 \\
\mathrm{kc} / \mathrm{s}\end{array}$ & $\begin{array}{l}1,000 \\
\mathrm{ke} / \mathrm{s}\end{array}$ & $\begin{array}{c}20,000 \\
\mathrm{kc} / \mathrm{s}\end{array}$ \\
\hline \multirow{3}{*}{ SB16... } & ${ }^{\circ} C$ & $h r$ & ${ }^{\circ} \mathrm{C}$ & $h r$ & Per- & & & & & & \\
\hline & 1,245 & $\begin{array}{r}1 \\
\ldots-\end{array}$ & $\begin{array}{l}1,375 \\
1,385\end{array}$ & 2 & \begin{tabular}{|r}
0.00 \\
\end{tabular} & $\begin{array}{l}1,930 \\
1,890\end{array}$ & $\begin{array}{l}1,850 \\
1,840\end{array}$ & $\begin{array}{l}1,810 \\
1,820\end{array}$ & $\begin{array}{l}33 \\
36\end{array}$ & $\begin{array}{r}74 \\
112\end{array}$ & $\begin{array}{l}60 \\
62\end{array}$ \\
\hline & 1,245 & & 1,420 & 2 & .00 & 1,920 & 1,850 & 1,790 & 36 & 119 & 62 \\
\hline \multirow{2}{*}{$\mathrm{B}_{2} \mathrm{~S} 95 \ldots$} & 1,200 & 1 & 1,310 & 2 & .05 & 860 & 830 & 820 & 83 & 61 & 28 \\
\hline & 1,200 & & 1,285 & 2 & .00 & 840 & 820 & 810 & 74 & 52 & 27 \\
\hline \multirow{2}{*}{ BT } & 1,245 & 1 & 1,385 & 2 & .05 & 1,460 & 01,410 & 1,360 & 79 & 93 & 50 \\
\hline & 1,245 & & 1,425 & 2 & .08 & 1,480 & 01,480 & 1,410 & 82 & 84 & 44 \\
\hline Bt $\approx \ldots$ & 1,245 & & & 1 & $\{.03$ & 1,690 & 01,650 & 1,670 & 134 & 74 & 28 \\
\hline $\mathrm{Bt} \mathrm{b}$ & 1,245 & & $\{1$, & 1 & $\{1.07$ & 1,330 & 01,300 & 1,330 & 98 & 144 & 78 \\
\hline
\end{tabular}

a $\mathrm{BaTiO}_{3}$ made with $\mathrm{TiO}_{2}$, grade $W D$.

b $\mathrm{BaTiO}_{3}$ made with $\mathrm{TiO}_{2}$, grade $R$.

Coating the specimens, particularly those having relatively high absorption, with wax or paraffin increased the values of $Q$. The improvement, however, was not permanent, for on standing a gradual decrease in $Q$ was noted.

At a frequency of $3,000 \mathrm{mc} / \mathrm{s}$, a greater difference was observed in the values of $Q$ than of $K$ compared with their respective values found at a frequency of $1 \mathrm{mc} / \mathrm{s}$, as indicated by the data in table 5. As most specimens had a dielectric constant that was too high for determination by this method, only these three specimens were measured at $3,000 \mathrm{mc} / \mathrm{s}$.

The thermal expansion of the specimens was high, ranging from 0.59 to 0.84 percent between

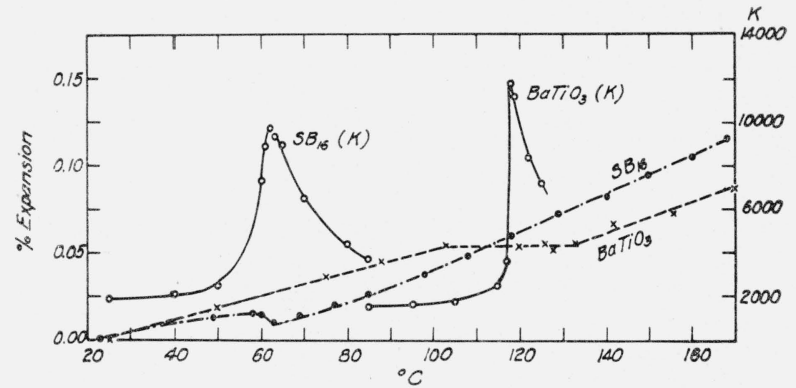

Figure 10.-Thermal expansion for a specimen of $\mathrm{BaTiO}_{3}$ and for SB16 (table 3) in the region of the peak dielectric constant, over the range $25^{\circ}$ to $170^{\circ} \mathrm{C}$.

Solid lines for dielectric constant and broken lines for thermal expansion.

room temperature and $700^{\circ} \mathrm{C}$, despite the wide variation in composition (table 9). Figure 10 illustrates a peculiar feature of the expansion curve for specimens with compositions in the join $\mathrm{BaO}: \mathrm{TiO}_{2}-\mathrm{SrO}: \mathrm{TiO}_{2}$. The flat section of these curves occurred in the range of temperature characterized by a peak in the dielectric constant.

TABLe 9.-Linear thermal expansion

\begin{tabular}{|c|c|c|c|c|c|c|c|c|c|}
\hline \multirow{2}{*}{$\begin{array}{l}\text { Specimen des- } \\
\text { ignation }\end{array}$} & \multicolumn{9}{|c|}{ Temperature range from $25^{\circ} \mathrm{C}$ to- } \\
\hline & ${ }_{\mathrm{C}}^{100^{\circ}}$ & ${ }_{\mathrm{C}}^{200^{\circ}}$ & ${ }_{\mathrm{C}}^{300^{\circ}}$ & ${ }_{\mathrm{C}}^{400^{\circ}}$ & ${ }^{500^{\circ}}$ & $\mathrm{C}_{\mathrm{C}}^{\circ}$ & ${ }^{700^{\circ}}$ & $\frac{800^{\circ}}{\mathrm{C}}$ & $\stackrel{900^{\circ}}{\mathrm{C}}$ \\
\hline $\mathrm{TiO}_{2}$ & $\begin{array}{l}\text { Per- } \\
\text { cent } \\
0.06\end{array}$ & $\begin{array}{l}\text { Per- } \\
\text { cent } \\
0.14\end{array}$ & $\begin{array}{l}\text { Per- } \\
\text { cent } \\
0.23\end{array}$ & $\begin{array}{l}\text { Per- } \\
\text { cent } \\
0.32\end{array}$ & $\begin{array}{l}\text { Per- } \\
\text { cent } \\
0.41\end{array}$ & $\begin{array}{l}\text { Per- } \\
\text { cent } \\
0.50\end{array}$ & $\begin{array}{l}\text { Per- } \\
\text { cent } \\
0.60\end{array}$ & $\begin{array}{l}\text { Per- } \\
\text { cent } \\
0.69\end{array}$ & $\begin{array}{l}\text { Per- } \\
\text { cent } \\
0.79\end{array}$ \\
\hline $\mathrm{BT} 18 \ldots$ & $\begin{array}{r}0.00 \\
.05\end{array}$ & $\begin{array}{r}0.14 \\
.14\end{array}$ & $\begin{array}{r}0.23 \\
.23\end{array}$ & $\begin{array}{r}0.32 \\
.31\end{array}$ & $\begin{array}{r}0.41 \\
.41\end{array}$ & $\begin{array}{r}0.50 \\
.50\end{array}$ & $\begin{array}{r}0.00 \\
.59\end{array}$ & 0.69 & 0.79 \\
\hline BT6 & .05 & .14 & .24 & .33 & .43 & .54 & .64 & & \\
\hline BT5 & .06 & .15 & .24 & .34 & .45 & .57 & .68 & & \\
\hline BT4 & .06 & .14 & .23 & .32 & .41 & .51 & .60 & .70 & \\
\hline BT3 & .06 & .16 & .26 & .37 & .48 & .59 & .71 & & \\
\hline BT $2.2 \ldots$ & .06 & .16 & .26 & .37 & .49 & .61 & .72 & & \\
\hline BT2 & .07 & .16 & .28 & .40 & .52 & .65 & .78 & & \\
\hline BT & .05 & .13 & .25 & .38 & .52 & .66 & .80 & & \\
\hline SB64 $\ldots$ & .07 & .18 & .30 & .42 & .55 & .67 & .80 & & \\
\hline SB29 $\ldots$ & .07 & .19 & .32 & .44 & .58 & .71 & .84 & & \\
\hline $\mathrm{SB} 29 \mathrm{~F}$ a & .07 & .19 & .29 & .41 & .54 & .68 & .79 & & \\
\hline SB16_... & .04 & .16 & .28 & .41 & .55 & .68 & .81 & & \\
\hline ST ..... & .07 & .17 & .29 & .40 & .51 & .63 & .74 & & \\
\hline ST2 $\ldots$ & .06 & .16 & .26 & .36 & .46 & .55 & .65 & .75 & \\
\hline ST4 $\ldots \ldots$ & .06 & .15 & .25 & .35 & .44 & .55 & .65 & & 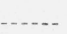 \\
\hline
\end{tabular}

a $3 \% \mathrm{MgF}_{2}$ added.

Although the construction of a phase diagram for this system was outside the scope of this investigation, there were indications, based on 
maturing temperatures, of the existence of compounds in various regions of the diagram, figure 2. For example, a binary compound in the region of $\mathrm{BaO}: 4 \mathrm{TiO}_{2}$ is suggested by the maturing temperature, dielectric constant, and X-ray spectrogram. In fact, a comparison of X-ray patterns for all the specimens in the system $\mathrm{BaO}-\mathrm{TiO}_{2}$ indicated the formation of other compounds in addition to $\mathrm{BaO}: 4 \mathrm{TiO}_{2}$ and $\mathrm{BaO}: \mathrm{TiO}_{2}{ }^{5}$ The maturing temperature of $1,350^{\circ} \mathrm{C}$ for specimens in the region 18 percent $\mathrm{BaO}, 28$ percent $\mathrm{SrO}, 54$ percent $\mathrm{TiO}_{2}$ is suggestive of a ternary compound, but the suggestion is not supported by data on the dielectric constant or by X-ray patterns.

\section{Conclusions}

Mature specimens (absorption less than 0.10 percent) can be made from mixtures of titanium dioxide with barium and strontium carbonates, which have compositions represented by points in the system $\mathrm{BaTiO}_{3}-\mathrm{Sr}^{\top} \mathrm{TiO}_{3}-\mathrm{TiO}_{2}$. The dielectric constant of these specimens varies from 34 to several thousand, whereas the $Q$ values vary from about 50 to several thousand. Most of these specimens exhibit a large negative temperature coefficient of dielectric constant, which is not too

${ }_{5}$ The authors are indebted to H. F. MeMurdie for the X-ray spectrograms and their interpretation. great in some to prevent their use as bypass and coupling condensers. A few have positive temperature coefficients, although that of one specimen $\left(\mathrm{BaO}: 5 \mathrm{TiO}_{2}\right)$ is practically zero. When properly fabricated, some of these titanate bodies could be used also as filter or storage condensers, and as delay lines for microwave signals.

\section{References}

[1] Eugene Wainer, High titania dielectrics, Trans. Am. Electrochem. Soc. 89 (April 1946). Preprint 89-3.

[2] A. von Hippel and associates, High dielectric constant ceramics, Report VII (August 1944). Titania ceramies II, Report XI (October 1945). (Laboratory for Insulation Research, Mass. Inst. of Tech., Cambridge, Mass.)

[3] B. Wul, Dielectric constants of some titanates, Nature 156, 480 (1945).

[4] German Patent 545,402.

[5] W. Schmidt, Determination of dielectric constants of crystals by means of electric waves, Ann. Physik [14] 9, 919 (1902); 11, 114 (1903).

[6] A. von Hippel, D. G. Jelatis, and W. B. Westphal, The measurement of dielectric constant and loss with standing waves in co-axial wave guides. (April 1943.) (National Defense Research Committee, Contract OEMsr-191. Mass. Inst. of Tech.)

[7] W. Jackson and W. Reddish, High permittivity crystalline aggregates Nature 156, 717 (1945).

Washington, September 18, 1946. 